\title{
KATASZTRÓFAVÉDELMI ÖNKÉNTESEK KÖZÖSSÉGI MÉDIA HASZNÁLATA
}

\section{THE SOCIAL MEDIA USE OF THE DISASTER MANAGEMENT VOLUNTEERS}

\author{
HÁBERMAYER Tamás \\ (ORCID: 0000-0002-6677-9163) \\ dr.habermaver.tamas@ \\ katved.gov.hu
}

\author{
TÚRINÉ BARTA Ágnes \\ (ORCID: 0000-0001-5782-3997) \\ agnes.turinebarta@ \\ katved.gov.hu
}

\author{
MUHORAY Árpád \\ (ORCID: 0000-0003-3832-293X) \\ muhoray.arpad@uni-nke.hu
}

\begin{abstract}
Absztrakt
A katasztrófavédelmi önkéntesek különböző módon, generációnként eltérö gyakorisággal és funkcióval használják a közösségi média nyújtotta lehetöségeket. Az elektronikus eszközök technológiai fejlödése, illetve a szolgáltatók által biztosított lehetőségek az internet elérését és ezen alkalmazások használatát egyre könnyebbé teszik. A fiatalabb generációk ezzel napi szinten együtt élnek, míg az idősebb generációk tagjai közül kevesebben képesek alkalmazkodni ezekhez. A közösségi média használata ugyanakkor számos lehetöséget biztosít - például szöveges és képi információk valós idejü megosztása, az önkéntes csoport szervezése vagy riasztás - de számos veszélyt is rejt magában. A szerzők az ár- és belvíz elleni védekezések jövőbeli szervezése érdekében vizsgálják a katasztrófavédelmi önkéntesek közösségi média használatát, és tesznek javaslatot a hatékony alkalmazáshoz.
\end{abstract}

Kulcsszavak: katasztrófavédelem, önkéntes, közösségi média, generációk

\begin{abstract}
The social media use of the disaster management volunteers vary in frequency and function according to different generations. The development of the electronic devices and the progress of the internet packages provided by different ISPs make the availability and the use easier. The younger generations live with this process every day, but fewer members of the older generations can adapt to this situation. The social media use provide numerous possibilities - for example: sharing text and picture information, organising a voluntary group, alert -, but has dangers as well. In this article, the authors examine the social media use of the disaster management volunteers, because of organising future inland water and flood defense, and make suggestions how can it be efficient in different ways.
\end{abstract}

Keywords: disaster management, volunteer, social media, generations 


\section{BEVEZETÉS}

Hasonlóan a világ legtöbb országához, az ár- és belvizek elleni védekezések során számos önkéntes segíti a veszélyhelyzetek elhárítását. A katasztrófavédelmi szervezet, felismerve az önkéntesek képességeit és hasznosságát, sokféle közremüködési lehetőséget teremt számukra. A települések valós kockázatokon alapuló felmérése során a veszélyforrások realizálódnak, a megfelelő védelmi erő tervezhetővé válik. Az azonosított kockázatok veszélyei ellen az önkéntesek is védekeznek, a veszély mértékétől függően egyénként, csoportként, vagy akár tömegként. Ez azonban nem lehet önálló, hiszen szorosan együtt kell müködniük a védekezésre hivatott állami és önkormányzati szervekkel, valamint a védekezés más, nem önkéntes résztvevőivel (például közfoglalkoztatottak, köteles polgári védelmi szervezetek). Egy másik megközelítésből az önkéntesek részvételét a védekezések szervezőinek tudatosan tervezni kell. Ismerni kell a jellemzőiket, az önkéntesek kategóriáit, az eszközök és az erőforrások lehetőségeit, valamint motivációjukat ahhoz, hogy azok a lehető leghatékonyabbak legyenek. Sajnos ez jelenleg nagyon alacsony hatásfokkal müködik. Tekintettel az ár- és belvízi kockázatok emelkedő szintjére, a változó és új veszélyforrásokra, a lehető legnagyobb hatékonyság elérése (így a sikeres védekezések esélyének növelése) szinte kötelezővé válik. Ez viszont csak úgy történhet, ha a védelmi feladatok jelentős része már a felkészülés időszakában megvalósul. Ennek egyik legfontosabb eleme lehet a tudományos vívmányok és az informatikai fejlődés tudatos, célhoz kötött, szervezett felhasználása. Egy-két emberöltővel ezelőtt szinte teljesen a tudományos fantasztikum világába tartozott, hogy két ember egy telefon segítségével videó-kapcsolatba lépjen egymással. A mai korban erre a leggyengébb kategóriájú okostelefon is képes egy applikáció és wifi, vagy egyéb megfelelő adatkapcsolat segítségével. Ráadásul a katasztrófavédelmi önkéntesek, csakúgy, mint az emberek többsége elöszeretettel és rendszeresen használja az okoseszközöket, amelyek lassan már teljesen beépülnek a mindennapok világába. Így egyre inkább elenyésző azok száma, akik nem akarnak, vagy nem tudnak ennek a folyamatnak a részévé válni. A kutatásunk szempontjából elsőként felmerül a kérdés, hogy mennyire valós és mekkora a távolság a generációk informatikai tudása, eszközhasználata és alkalmazása között. A második kutatandó terület, hogy vajon használhatóak-e a közösségi média alkalmazások a katasztrófahelyzetekre történő felkészülésre vagy az önkéntesek szervezésére. Harmadik kérdésként felvetődik, hogy a védekezések szervezőinek a megváltozott körülményekre, az okoseszközökre, a közösségi média használatra kell-e tudatosan készülniük?

\section{A KATASZTRÓFAVÉDELMI ÖNKÉNTESEK GENERÁCIÓS MEGOSZLÁSA}

A katasztrófavédelmi önkéntesek generációs megoszlását, katasztrófavédelmi önkéntesi kategóriába tartozását anonim kérdőív segítségével vizsgáljuk. A generációk életkori meghatározásánál Kissné András Klára doktori értekezésében [1] foglalt csoportokat (az életkor és a katasztrófavédelmi müveletekbe történő bevonhatóság miatt az Alpha generáció jelenlegi kizárásával), az önkéntesek kategóriái során Dr. Hábermayer Tamás cikkét [2] vesszük alapul.

\begin{tabular}{|c|c|}
\hline Generáció & Születési idő \\
\hline Veterán generáció & $1925-1945$ \\
\hline A Baby-Boom generáció & $1946-1964$ \\
\hline Az X generáció & $1965-1979$ \\
\hline Az Y generáció & $1980-1994$ \\
\hline A Z generáció & $1995-2009$ \\
\hline Az Alpha generáció & $2010-$ \\
\hline
\end{tabular}

1. táblázat A generációk (Szerzők készítése) 
A kérdések megválaszolása céljából egy on-line kérdőívet készítettünk, amelyet anonim módon kellett az érdeklődő katasztrófavédelmi önkénteseknek 2018.11.01-2018.11.15. közötti időszakban kitölteniük. Az adatgyüjtéshez és elemzéshez használt szoftver a Lime Survey program volt. ${ }^{1}$ A kérdések százalékos eredményei a matematikai szabályok alkalmazásával, 2 tizedes-jegyig történő kerekítéssel váltak véglegessé.

A kérdőívben öt fő kérdéscsoport (generációs kérdések, technikai eszközök használata, közösségi média alkalmazása, kockázatok ismerete, ár- és belvíz kérdések) kapcsán összesen 16 kérdést kellett megválaszolniuk a kitöltőknek. Az érintett időszak alatt önkéntes feladatot vállalóktól 187 kitöltés érkezett, amelyböl 155 teljes, 32 részleges (nem minden kérdésre adott választ) kitöltés volt.

Az első két kérdés a katasztrófavédelmi önkéntesek generációjára, valamint közösségbe tartozására vonatkozott. Amennyiben ugyanis egy önkéntes már csoportba szerveződött, akkor az katasztrófavédelmi szempontból egy magasabb képzettségi és szervezettségi fokot jelent a mentési müveletek végrehajtása kapcsán [2: 106-109]. Az önkéntesi csoport tagjai a szervezett összejövetelek, találkozók, felkészítések alatt sok katasztrófavédelmi ismeretet, gyakorlati fogást el tudnak sajátítani, így a „csoportba szerveződött” önkéntesek képzettebbé válnak az egyénhez képest.

Az alábbi táblázat az önkéntesi kategóriákat mutatja.

\begin{tabular}{|l|c|}
\hline \multicolumn{1}{|c|}{ Kategória } & Katasztrófavédelmi törvény [3] \\
\hline Állampolgárok & \\
(önkéntesen segítséget nyújtó személyek) & \\
Polgári védelmi szervezetek & Kat. 2.§ (1) \\
Önkéntes civil szervezet & Kat. 3.§ 21. \\
a) önkéntesen közremüködö karitatív szervezet & Kat. 18. § (1) \\
b) önkéntesen közremüködő társadalmi szervezet & \\
gazdálkodó szervezetek önkéntesei & \\
nemzetközi önkéntesek & \\
$\begin{array}{l}\text { a) megfigyelők } \\
\text { b) beavatkozók }\end{array}$ & \\
\hline
\end{tabular}

2. táblázat A katasztrófavédelmi önkéntesek kategóriái (Szerzők készítése)

A kérdőív első kérdéscsoportja a generációk vizsgálatára vonatkozott. A következő táblázat azt mutatja, hogy a kitöltők életkora alapján hogyan alakultak a kategóriák.

\footnotetext{
${ }^{1}$ Lime Survey: Világviszonylatban is professzionális szintű, nyílt forráskódú on-line adatgyüjtő és elemző szoftver (www.limesurvey.org)
} 


\begin{tabular}{|c|c|c|c|c|c|c|}
\hline \multirow{2}{*}{$\begin{array}{l}\text { Önkéntesek } \\
\text { kategóriái }\end{array}$} & \multicolumn{6}{|c|}{ Generációk } \\
\hline & $\begin{array}{l}\text { Veterán } \\
(1925- \\
1945)\end{array}$ & $\begin{array}{c}\text { A Baby- } \\
\text { Boom } \\
(1946- \\
1964) \\
\end{array}$ & $\begin{array}{c}X \\
(1965- \\
1979)\end{array}$ & $\begin{array}{c}\mathrm{Y} \\
(1980- \\
1994)\end{array}$ & $\begin{array}{c}\mathrm{Z} \\
(1995- \\
2009)\end{array}$ & $\begin{array}{l}\text { Nincs } \\
\text { válasz }\end{array}$ \\
\hline $\begin{array}{c}\text { Kitöltók százalékos } \\
\text { megoszlása }\end{array}$ & $0.53 \%$ & $17.11 \%$ & $41.18 \%$ & $25.67 \%$ & $3.21 \%$ & $12.30 \%$ \\
\hline $\begin{array}{l}\text { Állampolgár } \\
\text { (Önként segítséget } \\
\text { nyújtó személy) }\end{array}$ & $100 \%$ & $65,21 \%$ & $36,74 \%$ & $43,33 \%$ & $50,00 \%$ & $0 \%$ \\
\hline $\begin{array}{c}\text { Pv. szervezet } \\
\text { (önkéntesei) tagja }\end{array}$ & $0 \%$ & $0 \%$ & $20,41 \%$ & $16,67 \%$ & $16,67 \%$ & $0 \%$ \\
\hline $\begin{array}{c}\text { Önkéntesen } \\
\text { közremüködő } \\
\text { karitatív szervezet } \\
\text { tagja }\end{array}$ & $0 \%$ & $8,70 \%$ & $10,20 \%$ & $10,00 \%$ & $0 \%$ & $0 \%$ \\
\hline $\begin{array}{c}\text { Önkéntesen } \\
\text { közremúködő } \\
\text { társadalmi } \\
\text { szervezet tagja }\end{array}$ & $0 \%$ & $26,09 \%$ & $26,53 \%$ & $26,67 \%$ & $16,67 \%$ & $0 \%$ \\
\hline $\begin{array}{c}\text { Gazdálkodó } \\
\text { szervezet } \\
\text { önkéntese } \\
\end{array}$ & $0 \%$ & $0 \%$ & $0 \%$ & $0 \%$ & $0 \%$ & $0 \%$ \\
\hline $\begin{array}{l}\text { Nemzetközi } \\
\text { megfigyelö }\end{array}$ & $0 \%$ & $0 \%$ & $0 \%$ & $0 \%$ & $0 \%$ & $0 \%$ \\
\hline $\begin{array}{l}\text { Nemzetközi } \\
\text { beavatkozó }\end{array}$ & $0 \%$ & $0 \%$ & $6,12 \%$ & $3,40 \%$ & $16,67 \%$ & $0 \%$ \\
\hline
\end{tabular}

3. táblázat A katasztrófavédelmi önkéntesek generációk szerinti megoszlása (Szerzők készítése)

Az eredmények alapján az látható, hogy bár minden kategóriából volt kitöltő személy, de az X generáció tagjaitól érkezett a legtöbb kitöltés (41,18\%). Öket az Y $(25,67 \%)$, majd a Baby Boom követte (17.11\%). Csekély volt a $\mathrm{Z}$ generáció részvétele $(3,21 \%)$, valamint elenyésző a Veteráné $(0,53 \%)$. Nem érkezett be kitöltés gazdálkodó szervezet önkénteseitöl, valamint nemzetközi megfigyelőktől - amely várható volt annak tükrében, hogy talán ezen kategóriákból kerül ki Magyarországon jelenleg a legkevesebb önkéntes.

Feltűnő az X, Y, Z generációk közötti százalékos értékek drasztikus csökkenése a kitöltők között (X - 41,18\%, Y - 25,67\%, Z - 3,21\%), ami akár a katasztrófavédelmi önkéntesség csökkenö tendenciájára is utalhat. Ez egy elgondolkodtató folyamat, amely ha bekövetkezik, és nem változik az önkéntesek generációnkénti megoszlása és aránya, akkor az idő előrehaladtával, a Baby Boom, X és később az Y generáció kiöregedésével az önkéntesek száma minimálisra csökkenhet. Ha ez bekövetkezik, akkor ez a hiány egyértelmüen emberi erőforrás kiesést, katasztrófahelyzetben a létszám-többszörözési képesség elvesztését, így 
hatékonyság-vesztést jelent, és kiterjedt katasztrófák esetében egyértelmüen többletterhet és más erőforrások bevonását igényli majd a katasztrófavédelmi szervezettől.

A táblázatból látható, hogy a Baby Boom generáció esetében kiemelkedő az egyéni önkéntesség (Állampolgár - önként segítséget nyújtó személy kategóriából az arányuk $65,21 \%)$ szerepe. Ez azt jelenti, hogy ezen generáció még abba szocializálódott bele, hogy az emberek döntö többsége szükség esetén önállóan és önként segített a bajba jutottakon. A következő generációk esetében ezen arány (X - 36,74\%, Y 43,33\%) kimutathatóan, drasztikusan lecsökkent.

\section{A KATASZTRÓFAVÉDELMI ÖNKÉNTESEK INTERNET, SZÁMÍTÓGÉP, OKOSESZKÖZ HASZNÁLATA}

A következő kérdéscsoport az önkéntesek eszközhasználatára vonatkozott. Az alábbi táblázat bemutatja, hogy hogyan oszlanak meg az egyes generációk saját és munkahelyi használatú technikai eszközei.

\begin{tabular}{|c|c|c|c|c|c|}
\hline \multirow{2}{*}{ Eszközök } & \multicolumn{5}{|c|}{ Generációk } \\
\cline { 2 - 6 } & Veterán & Baby-Boom & X & Y & Z \\
\cline { 2 - 6 } & $(1925-1945)$ & $(1946-1964)$ & $(1965-1979)$ & $(1980-1994)$ & $(1995-2009)$ \\
\cline { 2 - 6 } & \multicolumn{3}{|c|}{ Saját használatú eszközök (kérdöívet kitöltök ennyi \%-a rendelkezik vele) } \\
\hline Asztali számítógép & $0 \%$ & $68,75 \%$ & $50.65 \%$ & $47.92 \%$ & $16.67 \%$ \\
\hline Laptop & $0 \%$ & $62.50 \%$ & $76.62 \%$ & $77.08 \%$ & $83.33 \%$ \\
\hline Táblagép & $0 \%$ & $25.00 \%$ & $24.68 \%$ & $43.75 \%$ & $83.33 \%$ \\
\hline Mobiltelefon & $0 \%$ & $68.75 \%$ & $85.71 \%$ & $95.83 \%$ & $100.00 \%$ \\
\hline Smart TV & $0 \%$ & $18.75 \%$ & $40.26 \%$ & $25.00 \%$ & $16.67 \%$ \\
\hline Egyéb eszköz & $0 \%$ & $0 \%$ & $3.90 \%$ & $0 \%$ & $16.67 \%$ \\
\hline Eszközök & & $($ kérdöívet kitöltök ennyi $\%$-a rendelkezik vele) & \\
\hline Asztali számítógép & $50 \%$ & $50.00 \%$ & $50.65 \%$ & $45.83 \%$ & $33.33 \%$ \\
\hline Laptop & $0 \%$ & $9.38 \%$ & $29.87 \%$ & $33.33 \%$ & $16.67 \%$ \\
\hline Táblagép & $0 \%$ & $6.25 \%$ & $9.09 \%$ & $10.42 \%$ & $33.33 \%$ \\
\hline Mobiltelefon & $0 \%$ & $18.75 \%$ & $28.57 \%$ & $20.83 \%$ & $33.33 \%$ \\
\hline Smart TV & $0 \%$ & $0 \%$ & $1.30 \%$ & $0 \%$ & $16.67 \%$ \\
\hline Egyéb eszköz & $50 \%$ & $0 \%$ & $2.60 \%$ & $0 \%$ & $16.67 \%$ \\
\hline
\end{tabular}

4. táblázat A katasztrófavédelmi önkéntesek eszközhasználata (Szerzők készítése)

A munkahelyi eszközök elemzésével célszerű kezdeni, mivel itt jelentős eltérés a generációk eszközhasználatában nincsen. Ez abból adódik, hogy a munkáltatók elsősorban a cég érdekeit veszik alapul, és az alapján biztosítják a munkaeszközöket. Ennek az ellenkezőjét bizonyítja a saját használatú eszközök elemzése, amely a kiemelt részeknél egyértelmü tendenciákra világít rá. A táblázat mutatja, hogy az asztali számítógépek esetében a Baby Boom generációtól (68,75\%) egy csökkenés figyelhető meg, amely már az X (50,65\%) és Y $(47,92 \%)$ generációnál is számottevő, de a $Z$ generációnál már kifejezetten alacsony értéket mutat (16,67\%). A saját használatú táblagépeknél már ennek az ellentettje figyelhető meg. A Baby Boom (25\%) és X $(24,68 \%)$ generációtól az Y-ra lépve $(43,75 \%)$ már kisebb arányú növekedés jelentkezik, de az 
Z-hez (83,33\%) érve az arány már meghaladja a kezdeti háromszorosát. Az okosmobilok megjelenése is drasztikus fejlödést mutat. A $Z$ generáció esetében ez $100 \%$, míg visszafelé haladva az Y (95,83\%), az X (85,71\%), a Baby Boom (68,75\%). A táblázatból megállapítható, hogy a generációk változásával változnak a preferenciák is, ennek egyik kézzelfogható formája például a mobil eszközök térhódítása. Ez azt hozza maga után, hogy egyre nagyobb lesz azon katasztrófavédelmi önkéntesek aránya, akik mobil okoseszközöket használnak, amellyel egyre többen lesznek internet és közösségi média segítségével elérhetőek. Ennek eredménye lehet, hogy egyre hatékonyabbá válhat például egy applikáció segítségével a katasztrófahelyzetekre történő felkészítés, vagy akár veszélyhelyzetben az állampolgárokból álló önkéntesi csoport létrehozása.

A kérdőív következő kérdése során a saját és munkahelyi internet elérési képességeket vettük vizsgálat alá.

\begin{tabular}{|c|c|c|c|c|c|}
\hline \multirow{2}{*}{ Órák } & \multicolumn{5}{|c|}{ Generációk } \\
\cline { 2 - 6 } & $\begin{array}{c}\text { Veterán } \\
(1925-1945)\end{array}$ & $\begin{array}{c}\text { Baby-Boom } \\
(1946-1964)\end{array}$ & $\begin{array}{c}\text { X } \\
(1965-1979)\end{array}$ & $\begin{array}{c}\text { Y } \\
(1980-1994)\end{array}$ & $\begin{array}{c}\text { Z } \\
(1995-2009)\end{array}$ \\
\cline { 2 - 6 } & \multicolumn{5}{|c|}{$\begin{array}{c}\text { Saját internet elérési képesség (kérdöívet kitöltők } \\
\text { enni \%-a rendelkezik vele a megadott órákra bontva) }\end{array}$} \\
\hline 0 óra & $100 \%$ & $3.12 \%$ & $2.60 \%$ & $0 \%$ & $0 \%$ \\
\hline $1-6$ óra & $0 \%$ & $43.75 \%$ & $54.55 \%$ & $54.17 \%$ & $50.00 \%$ \\
\hline $7-12$ óra & $0 \%$ & $9.38 \%$ & $3.90 \%$ & $10.42 \%$ & $0 \%$ \\
\hline $13-18$ óra & $0 \%$ & $0 \%$ & $1.30 \%$ & $2.08 \%$ & $0.00 \%$ \\
\hline $19-23$ óra & $0 \%$ & $0 \%$ & $0 \%$ & $2.08 \%$ & $0 \%$ \\
\hline 24 óra & $0 \%$ & $43.75 \%$ & $33.77 \%$ & $31.25 \%$ & $50.00 \%$ \\
\hline \multirow{2}{*}{ Órák } & & Munkahelyi internet elérési képesség (kérdóivet kitöltők \\
\hline 0 óra & $0 \%$ & $31.25 \%$ & $16.88 \%$ & $25.00 \%$ & $33.33 \%$ \\
\hline $1-6$ óra & $100 \%$ & $28.12 \%$ & $48.05 \%$ & $31.25 \%$ & $33.33 \%$ \\
\hline $7-12$ óra & $0 \%$ & $34.38 \%$ & $18.18 \%$ & $25.00 \%$ & $16.67 \%$ \\
\hline $13-18$ óra & $0 \%$ & $0 \%$ & $0 \%$ & $4.17 \%$ & $0 \%$ \\
\hline $19-23$ óra & $0 \%$ & $0 \%$ & $0 \%$ & $0 \%$ & $0 \%$ \\
\hline 24 óra & $0 \%$ & $3.12 \%$ & $12.99 \%$ & $14.58 \%$ & $16.67 \%$ \\
\hline
\end{tabular}

5. táblázat A katasztrófavédelmi önkéntesek Internet-elérési képessége (Szerzők készítése) 
A kitöltések alapján három észrevételt teszünk. Elsőként azt, hogy a saját internetelérésiképesség rendkívül magas a katasztrófavédelmi önkéntesek körében, hiszen a 0 órás (azaz az internetet elérni nem képes) kitöltők aránya a Veterán generáció kivételével minden más esetben 5\% alatti értéket mutat. Második észrevételünk az, hogy relatíve magas az internetet saját részről folyamatosan elérni képes (24 óra) válaszadók aránya - Baby Boom $(43,75 \%), X$ $(33,77 \%)$, Y $(31,25 \%), Z(50 \%)$. Harmadikként megállapítható, hogy a munkahely által biztosított 24 órás folyamatos internetelérés a generációk ,fiatalodásával” lassan, de emelkedő tendenciát mutat.

A második kérdéscsoport következő kérdése az elektronikus levelezésekre, az alkalmazások és programok által küldött friss hírek, üzenetek megtekintésének idejére vonatkozott.

\begin{tabular}{|c|c|c|c|c|c|}
\hline \multirow{2}{*}{ Kérdés: } & \multicolumn{5}{|c|}{ Generációk } \\
\cline { 2 - 6 } & $\begin{array}{c}\text { Veterán } \\
(1925-1945)\end{array}$ & $\begin{array}{c}\text { Baby-Boom } \\
(1946-1964)\end{array}$ & $\begin{array}{c}\mathrm{X} \\
(1965-1979)\end{array}$ & $\begin{array}{c}\text { Y } \\
(1980-1994)\end{array}$ & $\begin{array}{c}\mathrm{Z} \\
(1995-2009)\end{array}$ \\
\cline { 2 - 6 } & \multicolumn{2}{|c|}{$\begin{array}{c}\text { Egy átlagos napon mekkora idöközönként ellenőrzi elektronikus } \\
\text { levelezését, illetve az alkalmazásai, programjai által küldött friss } \\
\text { híreket, üzeneteket? }\end{array}$} \\
\hline 0-15 perc & $0 \%$ & $6.25 \%$ & $16.88 \%$ & $4.17 \%$ & $0 \%$ \\
\hline $15-30$ perc & $0 \%$ & $3.12 \%$ & $20.78 \%$ & $31.25 \%$ & $33.33 \%$ \\
\hline $30-120$ perc & $0 \%$ & $43.75 \%$ & $35.06 \%$ & $37.50 \%$ & $33.33 \%$ \\
\hline $121-240$ perc & $0 \%$ & $9.38 \%$ & $5.19 \%$ & $12.50 \%$ & $16.67 \%$ \\
\hline $240-720$ perc & $0 \%$ & $21.88 \%$ & $15.58 \%$ & $10.42 \%$ & $0 \%$ \\
\hline $721+$ perc & $0 \%$ & $15.62 \%$ & $2.60 \%$ & $4.17 \%$ & $16.67 \%$ \\
\hline Nem válaszolt & $100 \%$ & $0 \%$ & $3,91 \%$ & $0 \%$ & $0 \%$ \\
\hline 2 órán belül nézi & $0 \%$ & $53,12 \%$ & $72,72 \%$ & $72,92 \%$ & $66,66 \%$ \\
\hline
\end{tabular}

6. táblázat A katasztrófavédelmi önkéntesek eszköz-ellenőrzései (Szerzők készítése)

Az eredményeket megtekintve a generációk drasztikusan nem térnek el egymástól. Ha viszont összevonjuk a kapott idő-eredményeket, és a két órán belüli értékeket vizsgáljuk, akkor megállapíthatjuk, hogy a Baby Boom generáció több mint a fele, az X, Y, Z generációk legalább kétharmada 2 órán belül ellenőrzi az elektronikus eszközén beérkező újdonságokat. Mindezt kiemelkedő eredménynek tekinthetjük, amelynek jelentős hasznosulása lehet például a riasztási feladatok megvalósításánál. 
A kérdéscsoport utolsó kérdése az operációs rendszerek használatára vonatkozott.

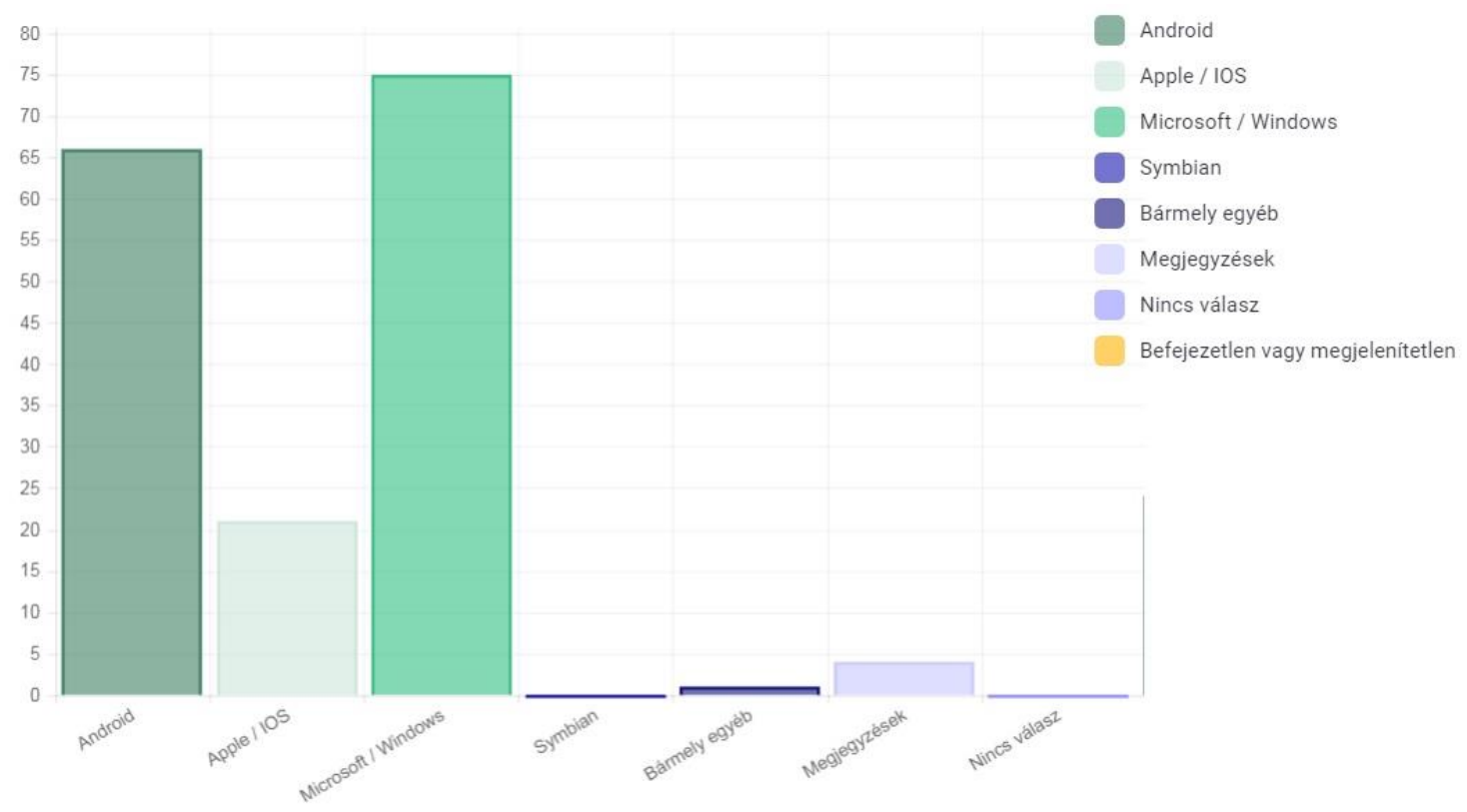

1. diagram A katasztrófavédelmi önkéntesek által használt operációs rendszerek kimutatása (Szerzők készítése)

Az oszlopdiagram mutatja az eredményeket. Az összes lehetőség közül a legjellemzőbb a Microsoft / Windows alkalmazása (jellemzően az X és Y generáció által kedvelt), de kimagasló értéket kapott az Android használata is (főleg Y, Z generációk.). A harmadik rendszertípus lett az Apple / IOS, a többi lehetőség száma arányait tekintve elenyésző. A katasztrófavédelmi önkéntesek részére írt szoftverek és alkalmazások kialakításánál erre fokozott figyelmet célszerü fordítani.

\section{A KATASZTRÓFAVÉDELMI ÖNKÉNTESEK KÖZÖSSÉGI MÉDIA HASZNÁLATA}

A kérdőíves kutatás harmadik csoportjába kerültek a katasztrófavédelmi önkéntesek által preferált közösségi média applikációkra, programokra vonatkozó kérdések. Elsőként vizsgáltuk, hogy a közösségi médiához tartozó szoftverek közül a kitöltőknek mely programokhoz van hozzáférése, és használja-e azokat aktívan. 


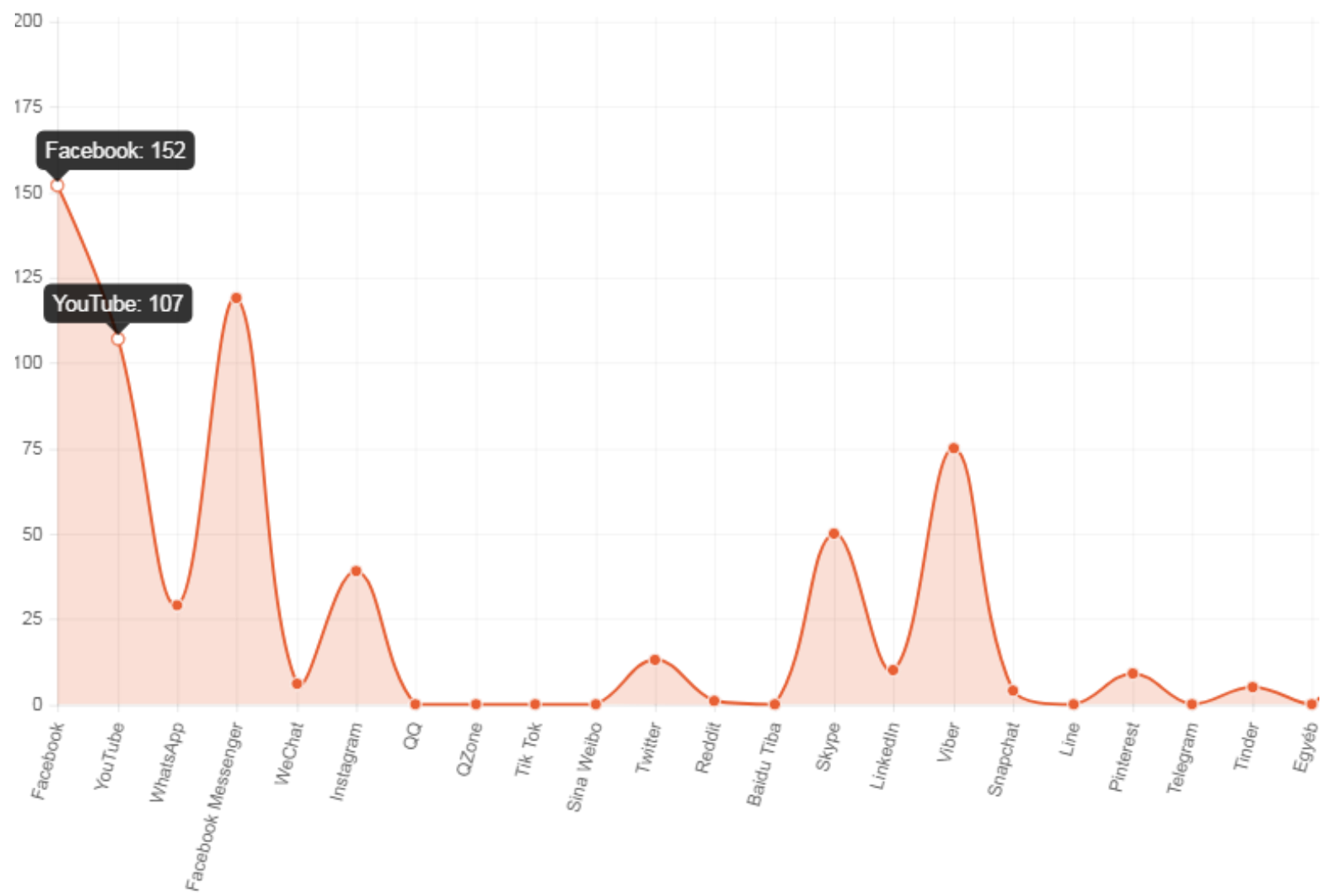

2. diagram A katasztrófavédelmi önkéntesek által használt közösségi média használata (Szerzők készítése)

A válaszok alapján egyértelmü volt a Facebook, a Facebook Messenger és a Youtube dominanciája, de sokan használják még a Viber, Skype, Instagram, WhatsApp programokat is. A kitöltők létszámához viszonyítva az arányok nagyon magasak, hiszen a válaszadók $81,28 \%$ a rendelkezik Facebook-, 63,64\% Facebook Messenger-, 57,22\% YouTube-hozzáféréssel. Ezen adat birtokában egyértelmüen vizsgálnunk kell a későbbiekben az önkéntesek Facebookhasználatát és a lehetőségeket a katasztrófavédelmi müveletek hatékonyságának növelésére. A többi program a magyar katasztrófavédelmi önkéntesek szempontjából kiesik, hiszen nagyon kevesen használják őket.

A kérdőív következő kérdése a közösségi programok alapvető használati preferenciájára vonatkozott. Azt vizsgálta, hogy milyen célzattal használják az önkéntesek a különböző közösségi szoftvereket. Az eredmények generációs bontásban a következőek: 


\begin{tabular}{|c|c|c|c|c|c|}
\hline \multirow{3}{*}{ Kérdés: } & \multicolumn{5}{|c|}{ Generáció } \\
\hline & $\begin{array}{c}\text { Veterán } \\
(1925-1945)\end{array}$ & $\begin{array}{l}\text { Baby-Boom } \\
(1946-1964)\end{array}$ & $\begin{array}{c}X \\
(1965-1979) \\
\end{array}$ & $\begin{array}{c}\mathrm{Y} \\
(1980-1994) \\
\end{array}$ & $\begin{array}{c}\text { Z } \\
(1995-2009)\end{array}$ \\
\hline & \multicolumn{5}{|c|}{ A közösségi programokat mely funkciókra használja ? } \\
\hline $\begin{array}{l}\text { Magam és családom } \\
\text { miatt használom }\end{array}$ & $0 \%$ & $34.38 \%$ & $50.65 \%$ & $62.50 \%$ & $0 \%$ \\
\hline $\begin{array}{l}\text { Kizárólag munka miatti } \\
\text { használat }\end{array}$ & $0 \%$ & $12.50 \%$ & $16.88 \%$ & $16.67 \%$ & $0 \%$ \\
\hline $\begin{array}{c}\text { Kapcsolattartás } \\
\text { ismerősökkel, közösség } \\
\text { csoporttagjaival }\end{array}$ & $100 \%$ & $75.00 \%$ & $75.32 \%$ & $91.67 \%$ & $66.67 \%$ \\
\hline $\begin{array}{c}\text { Káresemények / } \\
\text { rendkívüli események } \\
\text { kapcsán riasztás }\end{array}$ & $0 \%$ & $12.50 \%$ & $28.57 \%$ & $29.17 \%$ & $16.67 \%$ \\
\hline Tájékoztatás & $0 \%$ & $43.75 \%$ & $54.55 \%$ & $41.67 \%$ & $33.33 \%$ \\
\hline $\begin{array}{l}\text { Rendezvény és } \\
\text { csoportszervezés, } \\
\text { dokumentálás } \\
\end{array}$ & $0 \%$ & $28.12 \%$ & $38.96 \%$ & $31.25 \%$ & $50.00 \%$ \\
\hline Egyéb okokra & $0 \%$ & $0 \%$ & $3.90 \%$ & $0 \%$ & $16.67 \%$ \\
\hline
\end{tabular}

7. táblázat A katasztrófavédelmi önkéntesek közösségi program használata (Szerzők készítése)

A kapott értékek alapján több következtetést is tehetünk. Elsőként megállapíthatjuk, hogy a katasztrófavédelmi önkéntesek generációtól függetlenül elsősorban az ismerösökkel történő kapcsolattartásra használják a közösségi médiát (Piros színnel jelölve a táblázatban: 66,67 100\%). Másodikként realizálhatjuk, hogy szintén generációtól függetlenül, de nagyon alacsony értékeket mutat a kizárólag munka miatti használat $(0-16,67 \%)$. A Baby Boom $(34,38 \%), X$ $(50,65 \%)$, és Y $(62,50 \%)$ generáció esetében emelkedő tendenciát mutat a saját és a családdal összefüggő használat, de ez a Z generáció esetében drasztikusan $(0 \%)$ lezuhan. Ez utalhat a generációk közötti különbségekre, és érzékelteti, hogy a $Z$ generáció önkifejezése és közösségi média használata teljesen más irányt is jelenthet. $\mathrm{Az} X$ generációnál a legmagasabb a tájékoztatás értéke (54,55\%), de jelentős a Baby Boom (43,75\%) és Y generációé is $(41,67 \%)$. Érdekes értékeket figyelhetünk meg a rendezvény- és csoportszervezésnél, valamint az események dokumentálásánál. A Veterán egyértelmủen a legalacsonyabb $(0 \%)$, a Baby Boom $(28,12 \%)$ és az Y $(31,25 \%)$ közepes értékeket mutat, az X $(38,96 \%)$ és a $Z(50,00 \%)$ viszont már egyre inkább használja erre a közösségi médiát. Végül katasztrófavédelmi szempontból a legfontosabb: megfigyelhető, hogy különösebb felkészítés nélkül a katasztrófavédelmi önkéntesek X $(28,57 \%)$ és Y $(29,17 \%)$ generációjának közel harmada már most használja káresemények kapcsán riasztásra ezen programokat.

A kérdőív következő kérdésével kapcsolatban generációktól függetlenül azt vizsgáltuk, hogy mennyire ismerik a katasztrófavédelmi önkéntesek a hivatalos katasztrófavédelmi mobil applikációt, a VÉSZ-t (Veszélyhelyzeti Értesítési Szolgáltatást) [4]. A kérdés megválaszolásához több lehetőséget is biztosítottunk, amelyből a kitöltőnek választania kellett. 


\begin{tabular}{|c|r|}
\hline \multicolumn{2}{|c|}{$\begin{array}{c}\text { Beugrik -e azonnal, hogy mi az a VÉSZ } \\
\text { katasztrófavédelmi és lakossági szempontból? }\end{array}$} \\
\hline Válasz & Százalék \\
\hline Igen, egy rendkívüli jogrendi időszak. & $8.11 \%$ \\
\hline $\begin{array}{c}\text { Igen, a Katasztrófavédelem weboldalán } \\
\text { egy kihirdető felület. }\end{array}$ & $16.22 \%$ \\
\hline $\begin{array}{c}\text { Igen, egy applikació. } \\
\text { Igen, egy jelzés a katasztrófavédelmi } \\
\text { erök és eszközök alkalmazásának } \\
\text { valószínűségére. }\end{array}$ & $11.71 \%$ \\
\hline Nem. & $30.63 \%$ \\
\hline Nincs válasz & $0.90 \%$ \\
\hline
\end{tabular}

8. táblázat A katasztrófavédelmi önkéntesek VÉSZ ismerete (Szerzők készítése)

A válaszok alapján a katasztrófavédelmi önkéntesek mindösszesen egyharmada $(32,43 \%)$ ismeri csak a VESZ alkalmazást, egy részük egy rendkívüli jogrendi időszaknak gondolja $(8,11$ \%), másik részük a katasztrófavédelem weboldalán egy kihirdető felületként tartja számon $(16,22 \%)$. Az önkéntesek közül van, aki egy jelzésnek gondolja (11,71\%), és közel harmaduk (30,63\%) egyáltalán nem ismeri.

\section{A KATASZTRÓFAVÉDELMI ÖNKÉNTESEK VESZÉLYEZTETŐ HATÁSOK, KOCKÁZATOK ISMERETE}

A következő kérdéscsoport kérdéssora a katasztrófavédelmi feladatok kockázatalapú megközelítésével [5:113] a katasztrófavédelmi önkéntesek saját környezetének, és a veszélyek kiemelt kockázati helyszíneinek ismeretére vonatkozott. A 187 kitöltő közül 147-en válaszoltak érdemben a kérdésekre, amelyekben a veszélyforrásokat, katasztrófa-kockázatokat soroltuk fel (a teljesség igénye nélkül). Az önkéntesek a helyi viszonyok ismerete és a saját alapvető felkészültség osztályozásával egy 1-10 pontig terjedő skálán értékeltek. 


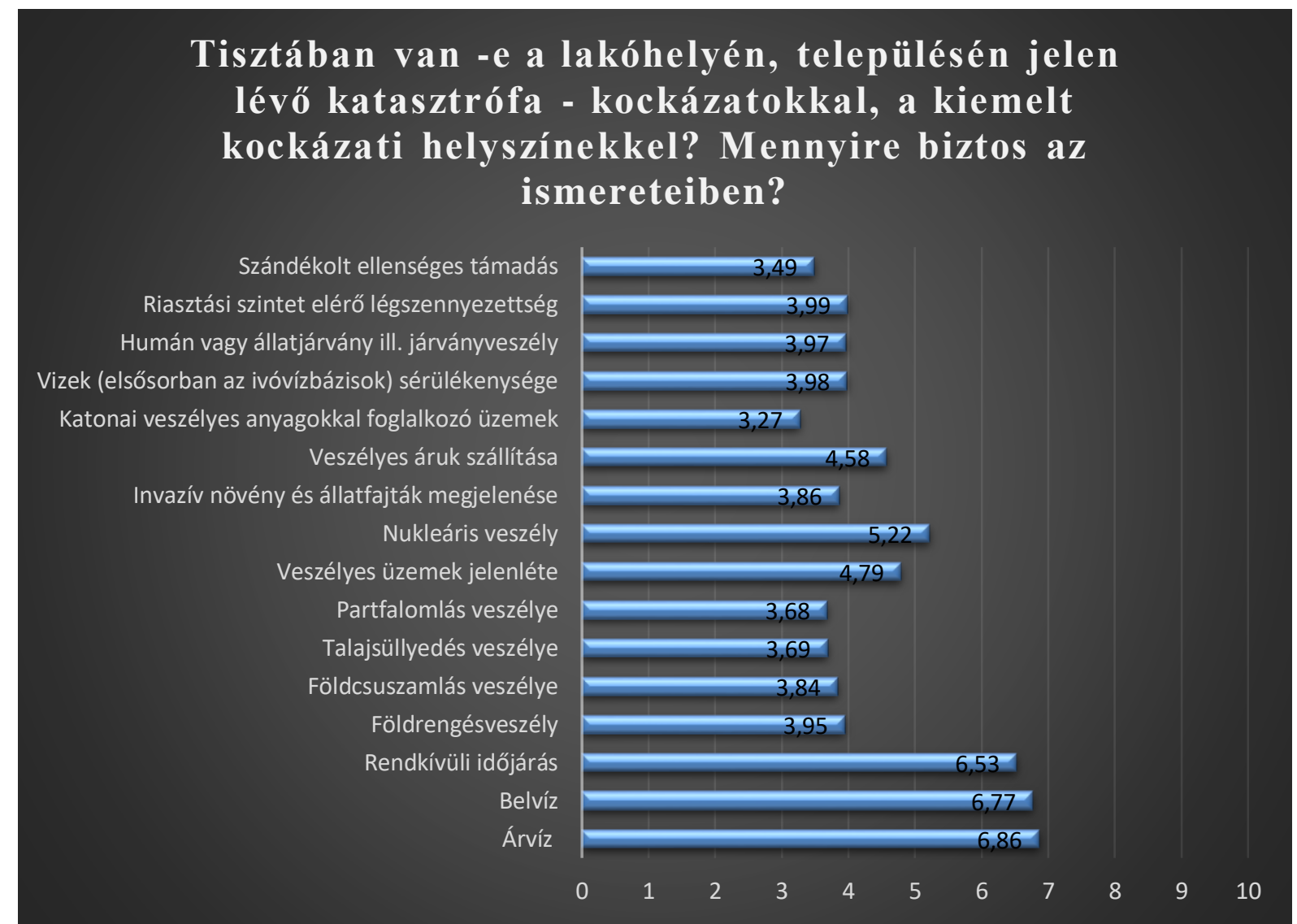

3. diagram A katasztrófavédelmi önkéntesek kockázat-ismerete (Szerzők készítése)

Az eredmények alapján kijelenthetjük, hogy a legmagasabb szintü felkészültséggel az ár- és belvíz kategóriában rendelkezünk, amely a rendszeres képzéseknek, és a számos ár- és belvízi felkészítésnek köszönhető. A többi katasztrófa-kockázat és veszélyeztető hatás szempontjából egyedül a nukleáris veszély lépi még át a 10-es skálán az 5-ös értéket, amely elsősorban annak köszönhető, hogy ebben a témakörben szintén rendszeresen történik lakossági tájékoztatás és felkészítés. A többi veszélyeztető hatás esetében (akár a rendszeres felkészítések ellenére) ugyanakkor az önkéntesek ismeretszintjét (önmaguk által értékelten) mindenképpen emelni kell a hatékony alkalmazáshoz, mivel az jelenleg meglehetősen alacsonynak tekinthető a kérdöívek alapján. Ezen mutatók tükrében viszont indokolttá válhat a különbözö katasztrófavédelmi felkészítéseken fokozottan kitérni a helyi veszélyeztető hatások bemutatására, a felismeréshez és a védekezésekhez szükséges ismeretekre, különösképpen akkor, ha önkéntes erök és eszközök bevonása is történik.

\section{A KATASZTRÓFAVÉDELMI ÖNKÉNTESEK ÁR- ÉS BELVÍZ ELLENI VÉDEKEZÉSSEL KAPCSOLATOS ISMERETEI}

A kérdőív utolsó kérdéscsoportja az ár- és belvíz elleni védekezéssel kapcsolatos önkéntesi ismereteket vizsgálta mélyebben. Az első kérdés kitöltésével a katasztrófavédelmi önkéntesek lakóhelyén jelen lévő ár- és belvízi kockázat-ismeretét, az ismeretek és felkészültség származását vizsgáltuk. 


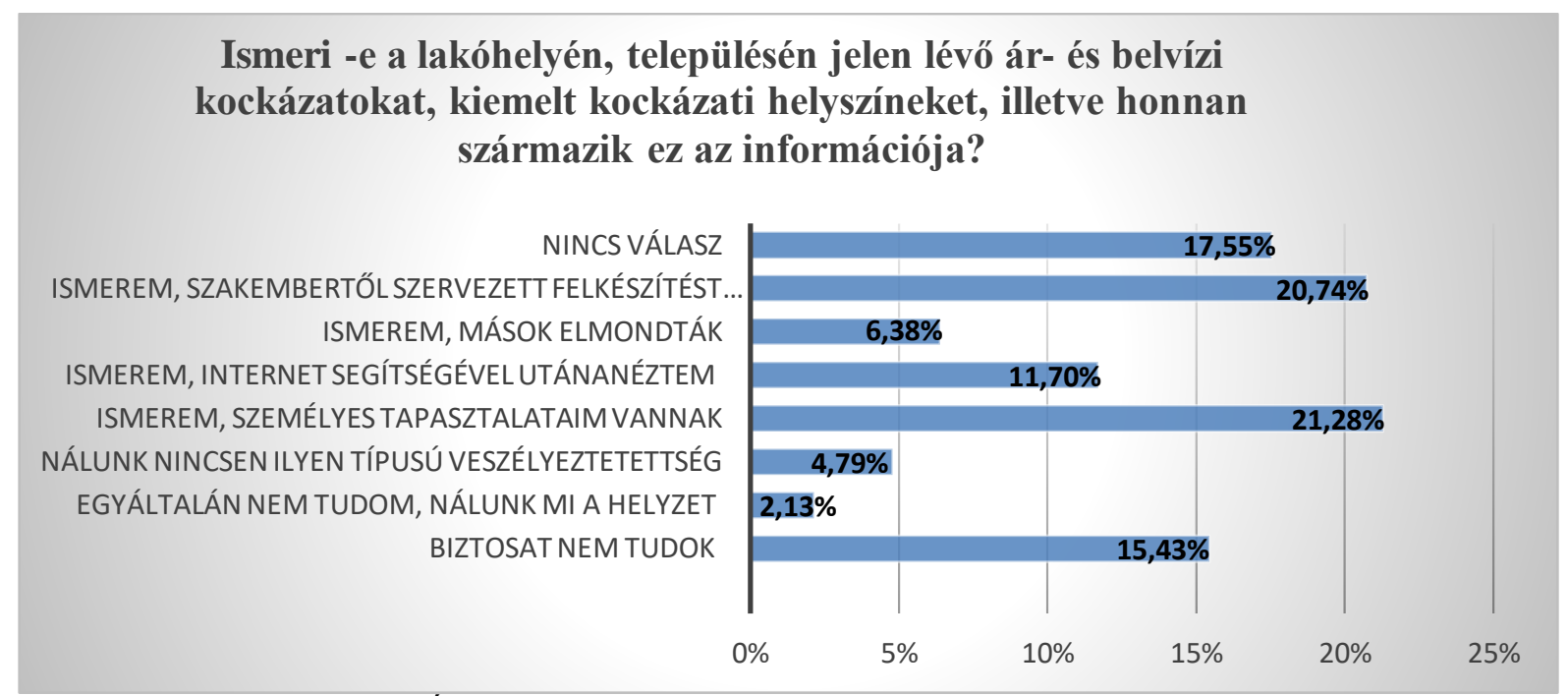

4. diagram Ár- és belvízi kockázatok, kiemelt helyszínek ismerete (Szerzők készítése)

A korábbi felmérések alapján az ár- és belvízre vonatkozó kockázatokkal vannak tisztában a legtöbben, ugyanakkor a kapott kitöltések alapján alacsonynak tekinthető azon katasztrófavédelmi önkéntesek száma, akik szakembertől és szervezett formában kaptak felkészítést (20,74\%). Ezt a számot talán kiegészíthetjük azokkal a személyekkel, akiknek személyes tapasztalatai vannak (21,28\%), így 42,02\%-a az önkénteseknek tekinthetö alapvetően felkészültnek egy ilyen típusú veszély elhárítására. További két kategória [Ismerem, Internet segítségével utánanéztem $(11,70 \%)$, valamint Ismerem, mások elmondták $(6,38 \%)$ ] összeredménye $18,08 \%$, amelyet nem lehet biztos tudásnak tekinteni a gyakorlati ismeretek hiánya miatt. A felkészítésen és védekezésen részt nem vett önkéntesek aránya $15,43 \%$ (Biztosat nem tudok) $+2,13 \%$ (Egyáltalán nem tudom, nálunk mi a helyzet) $+17,55 \%$ (Nincs válasz $)=35,11 \%$, amely magas értéknek tekinthető. A legmagasabb szintű hatékonyság elérésének alapfeltétele lenne, hogy mindenki a szintjének megfelelö felkészítésben részesüljön, és a védekezéshez szükséges tudással rendelkezzen.

A következő kérdés az önkéntesek (lakosság) részére hozzáférhető, nyílt adatbázisra vonatkozott, amelynek segítségével megtekinthető az adott település ár- és belvíz veszélyeztetett része. A kérdésre a megoldást elsősorban a települések településrendezési terve jelentette volna, amely az önkormányzatoknál, legtöbbször nyílt, elektronikus változatban elérhető. Ez képezheti ugyanis az alapját az adott település vizek kártételei elleni védekezésének, amely kiemelten fontos lehet például az önkéntesi felkészülés szempontjából. Amennyiben ugyanis a kockázati helyszínek nem ismertek, akkor a védekezés szervezése sem lehet hatékony. 


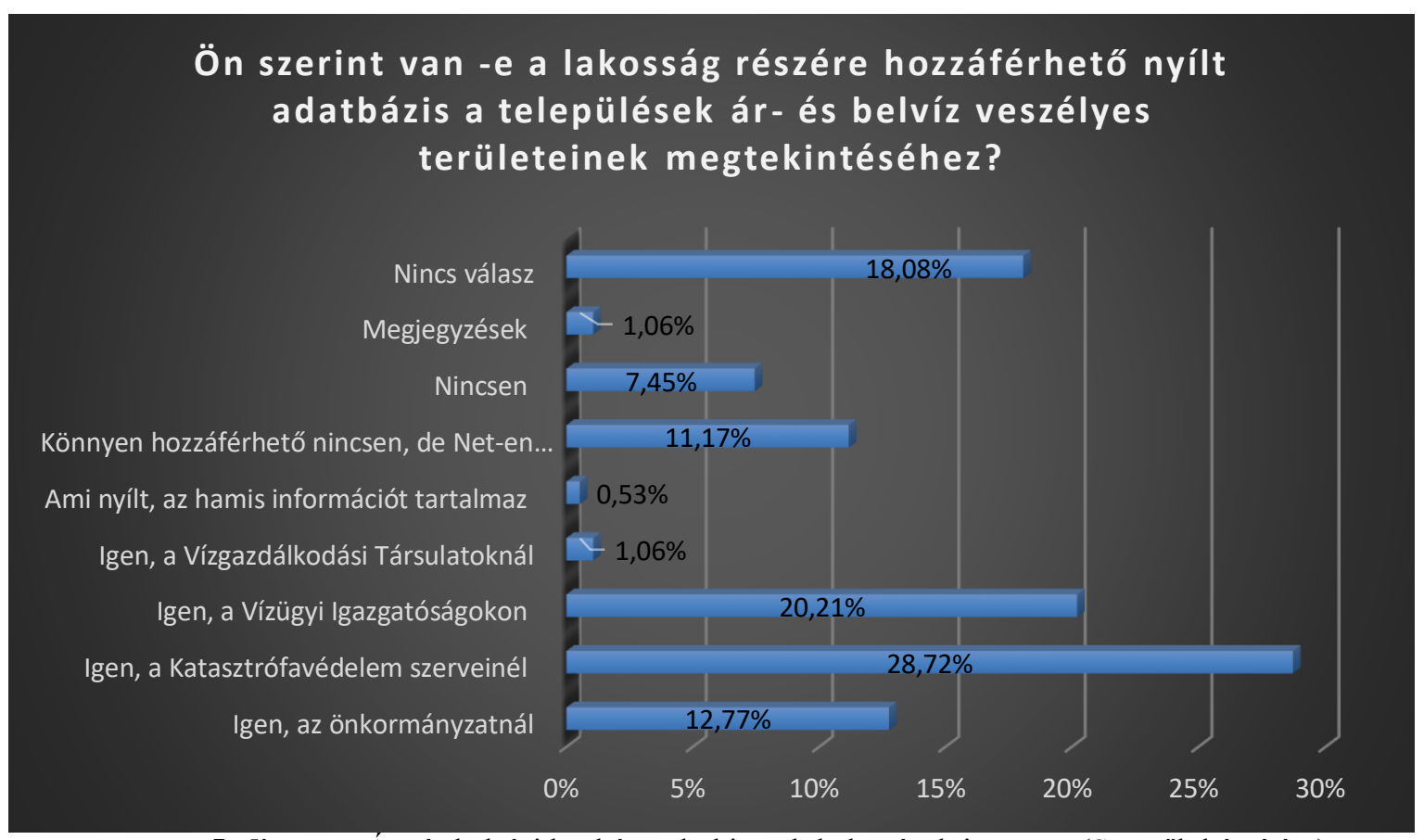

5. diagram Ár- és belvízi kockázatok, kiemelt helyszínek ismerete (Szerzők készítése)

A számos ár- és belvízi felkészítés ellenére is a „helyes” választ a kitöltők mindösszesen $12,77 \%$-a ismerte. A kérdést sokan a katasztrófavédelem szerveihez rendelték (28,72\%), illetve a vízügyi igazgatóságokhoz $(20,21 \%)$ telepítették. Természetesen ők is készítenek védelmi terveket, ezek azonban nem a lakosság széles körének szólnak, hanem az ár- és belvíz elleni védekezések rendszerszintü szervezését szolgálják.

Mindenképpen meg kell említenünk, hogy rendelkezésre áll és használható egy nyílt, hivatalos online weboldal, a Vízügyi Geoinformatikai Portál [6] az ár- és belvízi veszélyeztetések megismeréséhez:

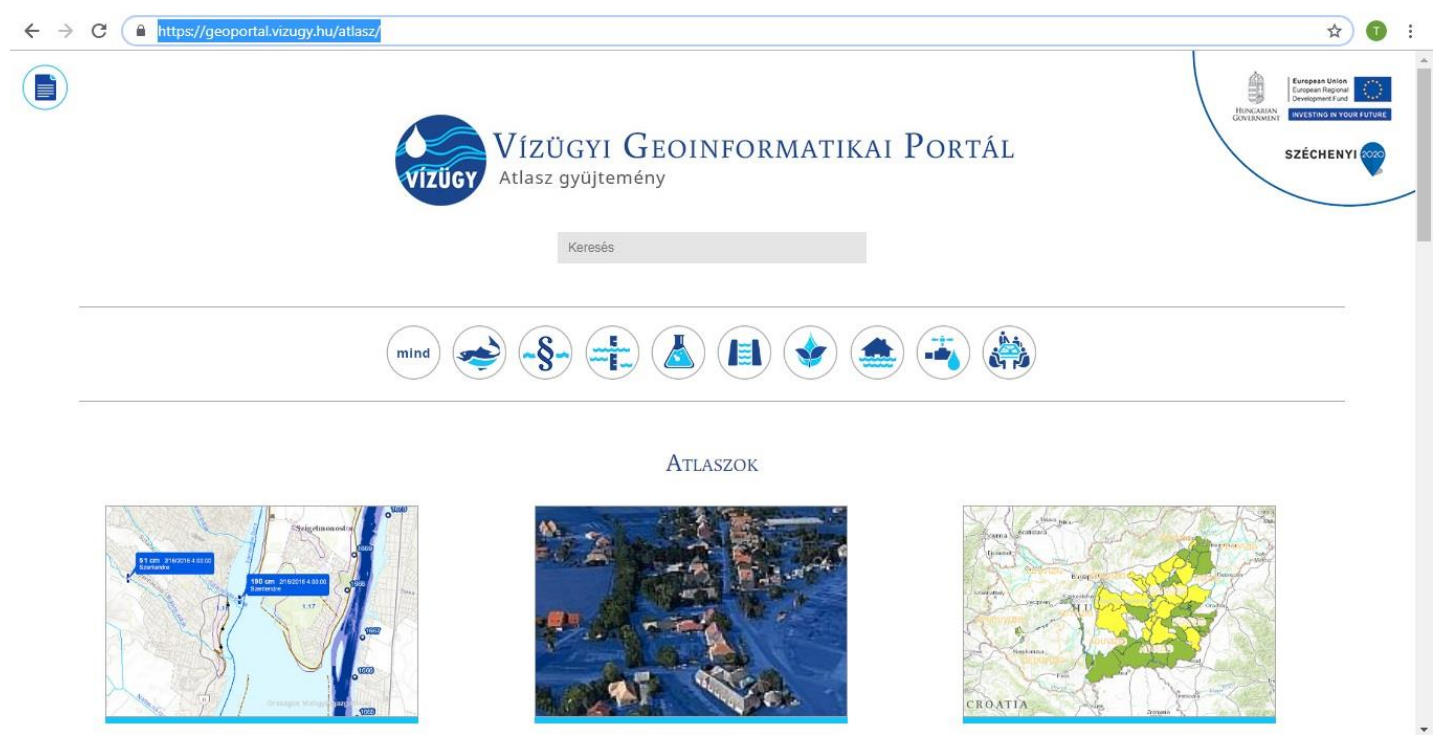

1. kép Vízügyi Geoinformatikai Portál [6] 


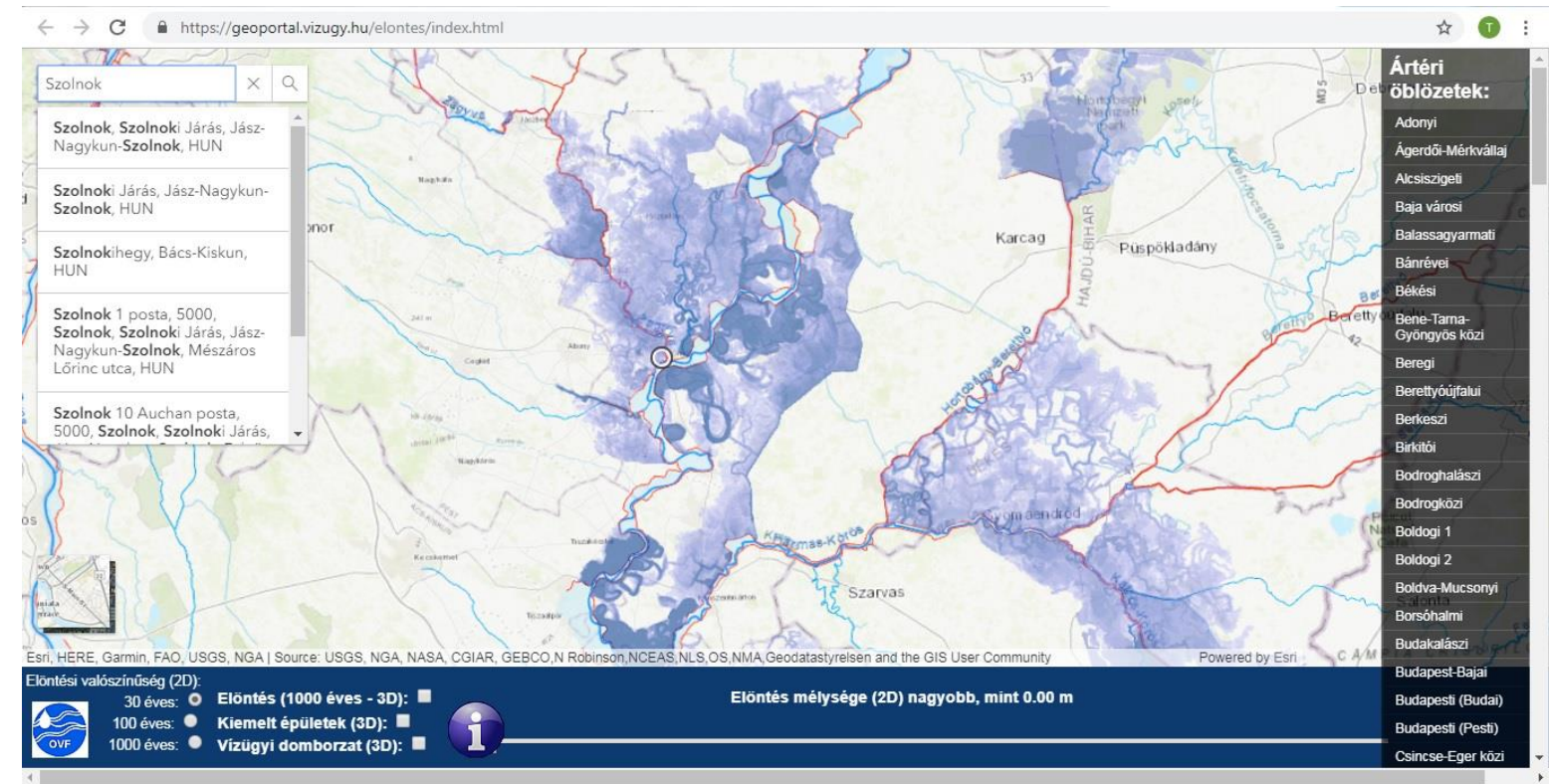

2. kép Vízügyi Geoinformatikai Portál - Árvízi elöntések valószínűsége [6]

Sok esetben ugyanis rendkívül nehézkes a településrendezési tervek megtalálása (így például a települési kiemelt kockázati helyszínek megismerése), valamint azok általában pdf formátumúak és rendkívül nagy, többszáz MB-nyi méretűek, nehezen kezelhetőek. Ezért a kérdőív következő kérdésében azt vizsgáltuk, hogy az internet és számítástechnika használatával vajon át lehetne-e hidalni ezen akadályt, és jelentősen leegyszerüsíteni a védekezésekhez szükséges információk biztosítását. Ennek megoldása lehetne az önkormányzatok weboldalain egy olyan pont létrehozása, ahol ezen adatok rendkívül egyszerűen és gyorsan, tehát felhasználóbarát módon hozzáférhetőek lehetnének.

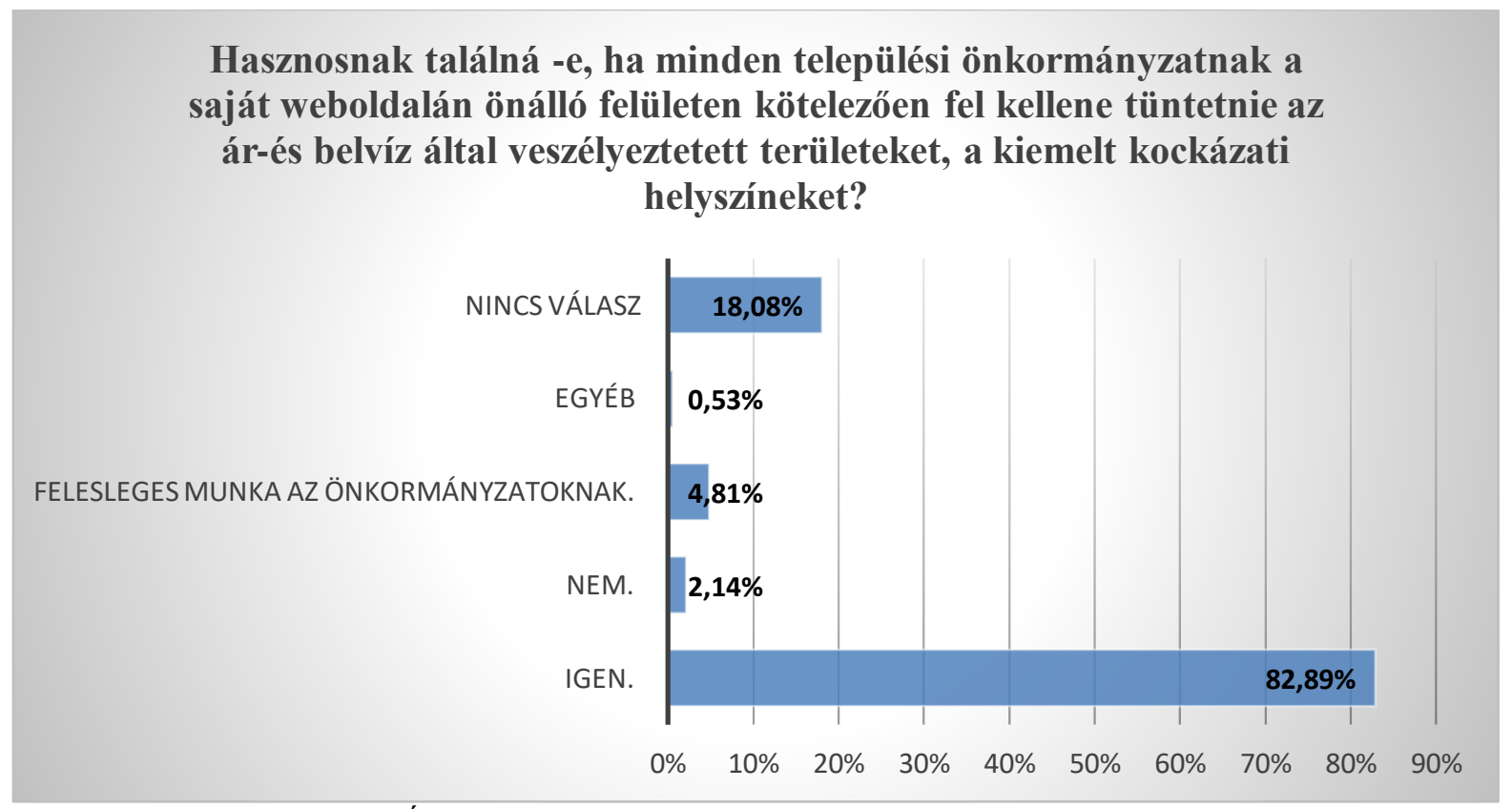

6. diagram Ár- és belvízi kockázatok, kiemelt helyszínek ismerete (Szerzők készítése)

A katasztrófavédelmi önkéntesek válasza elég egyértelmü és meggyőző volt, hiszen 82,89\%uk szeretné, ha a települések ár- és belvíz fenyegetettsége önállóan megjelenne minden települési honlapon. Ezáltal sokkal könnyebben megismerhetőek lennének a veszélyeztető 
hatások, hatékonyabbá válhatna az információáramlás, és javulna a tanítás, illetve a kiképzés folyamata.

A kérdöív zárásaként, az utolsó kérdéssorban feltételezzük, hogy lesz olyan applikáció a későbbiek folyamán, amely hatékonyabbá teheti a katasztrófavédelmi önkéntesek szervezését, beavatkozásait. A program létrehozása során kiemelt fontossággal bír a felhasználók véleménye, ezért a kitöltőknek az alábbi táblázatban található tételek fontosságát kellett értékelni egy 1-10-ig terjedő skálán. (Lehetőség nyílt a kitöltő részéről saját ötleteket is hozzátenni.)

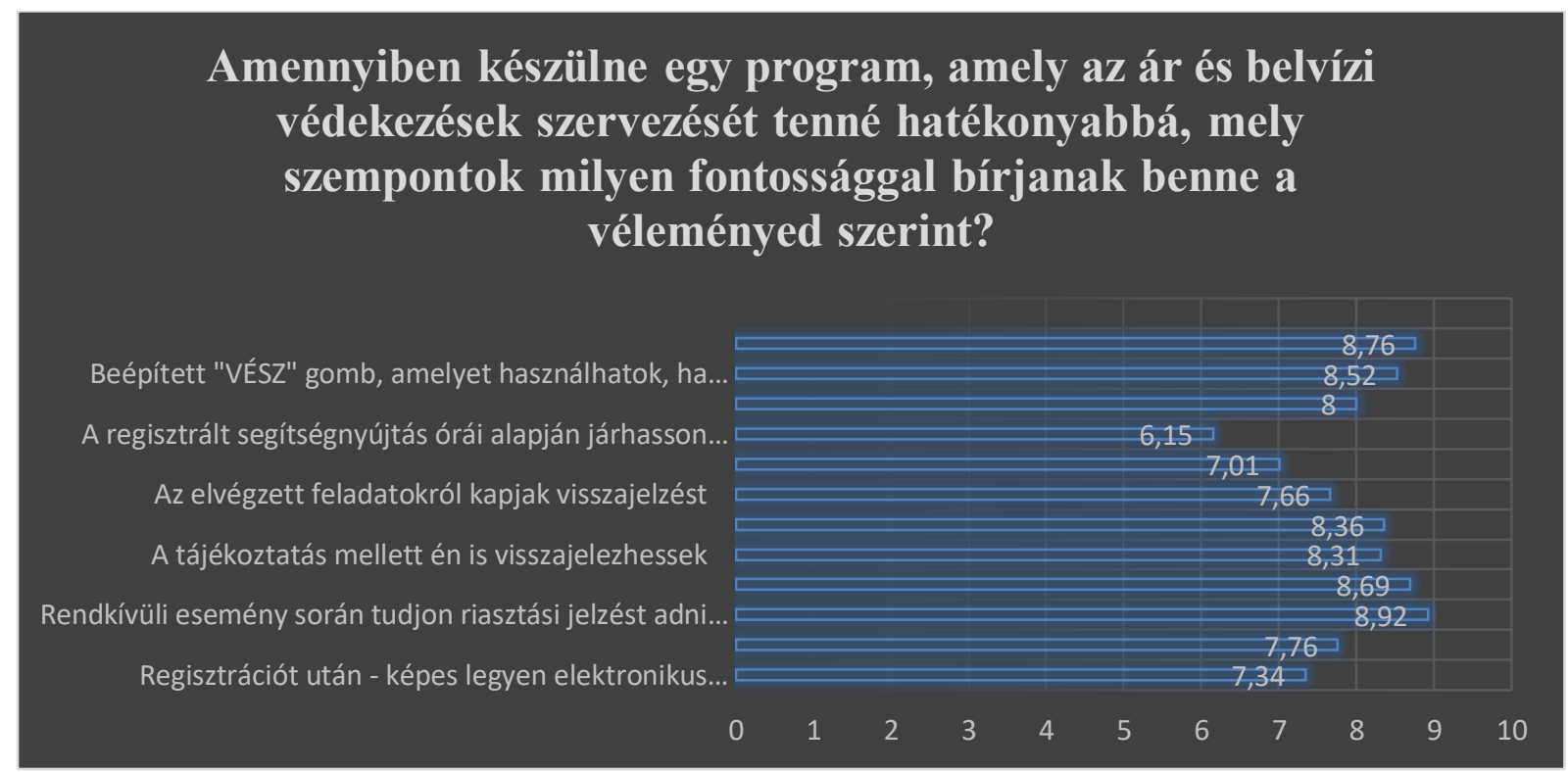

7. diagram Ár és belvízi kockázatok, kiemelt helyszínek ismerete (Szerzők készítése)

A kapott válaszok alapján a javaslatok minden tétele kiemelkedően lényeges, mégis különösen fontos közülük a biztonságra vonatkozó három tétel. A legmagasabb értékelést a „Rendkívüli esemény során tudjon riasztási jelzést adni nekem” - (8,92 pont) kapta, amely könnyen érthető, hiszen a riasztás alaptétele bármely katasztrófavédelmi müveletnek (Enélkül az el sem indul.) A saját biztonságra vonatkozik a „VÉSZ” gomb - (8,76 és 8,52 pont), amelynek akkor van szerepe, ha a használó is veszélybe kerül. Ilyen esetekben egyetlen gombnyomásra beindulhat a segélyhívó, valamint a használt okoseszköz GPS moduljának automatikus bekapcsolása. Az eszköz helymeghatározása után az applikáció azonnal továbbítaná a pontos koordinátákat a segélyhívó központba, ezáltal jelentősen növelhető a beavatkozások hatékonysága (hiszen a helyszín beazonosításának pontossága nagyságrendekkel javulhat, valamint az ideje drasztikusan lerövidülhet). Példaként szolgálhat az ECHO112 Web Emergency Locator [7] program, amely már évek óta rendelkezik hasonló funkciókkal. Ezen alkalmazást Svájcban használják, - miután az ország veszélyhelyzeti szolgálatai négy éven keresztül sikeresen tesztelték - és világszintü alkalmazásra (akár Magyarországos is használható) bocsájtották.

További külföldi példa a németországi NINA - Die Warn-App des BBK. A Szövetségi Lakosság- és Katasztrófavédelmi Hivatal ingyenesen letölthető figyelmeztető applikációja különböző veszélyhelyzetekről nyújt tájékoztatást, továbbá az időjárási előrejelzéseken, információkon túl árvízi híreket is közöl. Hasznosságát tovább erősíti az a szolgáltatása, hogy az alkalmazáson veszélyhelyzeti tippeket is olvashatnak az azt letöltők. [8] Számos további applikáció (pl. Meteora, Tavihar, Hydroinfo, Szív City, Juh RV, Warm Wetter, Drk App) foglalkozik lakosságtájékoztatással, amelyről további információkat kaphatunk Teknős László publikációjábó1 [9]. 


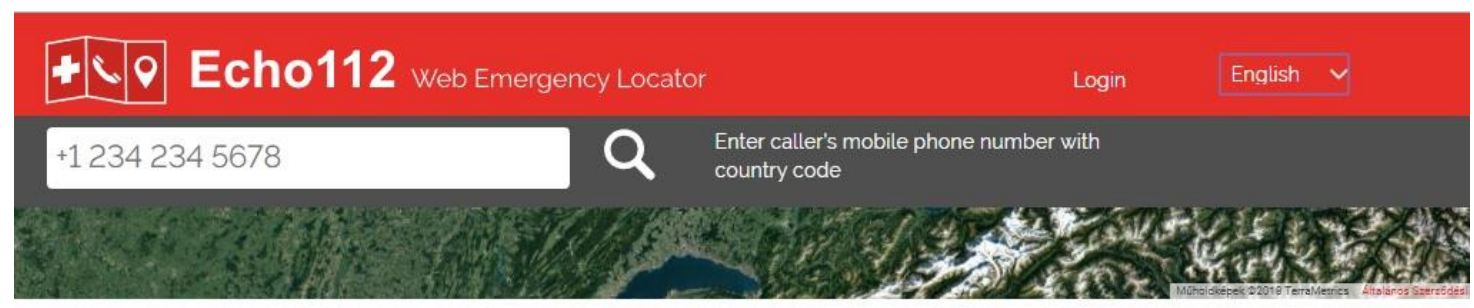

Get the Web Emergency Locator PRO

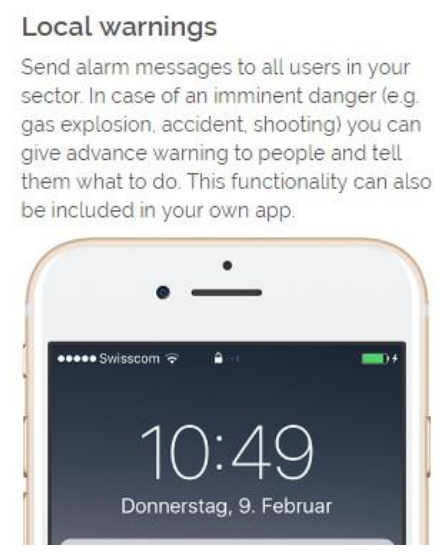

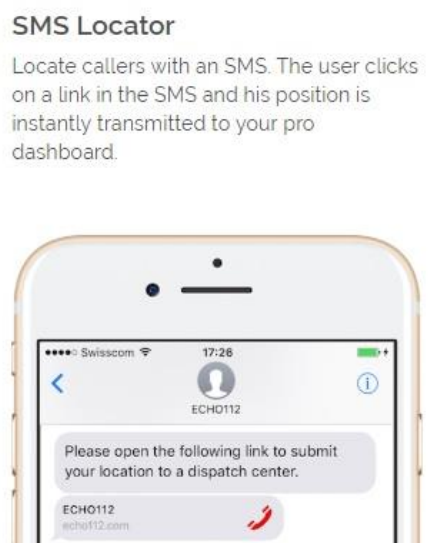

3. kép Az Echo112 program weboldala [7]
Custom emergency number

When users or employees are on site. they have immediate access to your local emergency number:

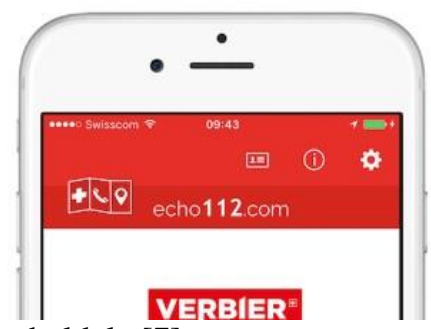

\section{A KÉRDÖÍV KÉRDÉSEINEK ÖSSZESÍTETT EREDMÉNYEI}

A korábban részletezett eredmények alapján megállapítható, hogy az eltérő generációk különböző mértékben használják tudatosan a technikai eszközöket és a közösségi médiát, viszont a generációk fiatalodásával az arány egyre javuló tendenciát mutat. Így az Y generáció részéröl 95,83\%-a, a $Z$ részéröl 100\%-a a válaszadóknak használ okostelefont és természetesen különböző programokat, applikációkat. Nagyon jelentős azok száma, akik a számítástechnikai és okoseszközök segítségével szinte állandó internetkapcsolattal rendelkeznek, és számukra már szintén nem jelenthet gondot a különböző programok (Facebook, Skype, Viber, stb...) használata, az információk rendkívül gyors továbbítása, vagy az önkéntesek meghatározott célnak megfelelő csoportba szervezése. Ennek felismerése és használata egy-egy védekezés során jelentősen megnövelheti a katasztrófavédelmi müveletek hatékonyságát. Optimálissá viszont csak akkor válik, amennyiben már a felkészülés időszakában, katasztrófavédelmi céllal, az önkéntesekkel közösen alakítható ki a rendszere. Annak tudatában, hogy generációktól függetlenül szinte mindenki rendelkezik napjainkban mobil okoseszközzel, ezt mindenképpen indokolt kihasználni a hatékonyság növelése érdekében. Ennek két útja lehet, elsőként vagy a már meglévő programokat és applikációkat használjuk (például Facebook-on - egy helyi szintü Települési Dunai Árvízvédekező zárt csoport létrehozása és működtetése), vagy második lehetőségként egy önálló alkalmazást hozunk létre, amely alkalmas a célfeladat ellátására.

A második hipotézisünkre is egyértelmü válasz adható. Mivel a közösségi média alkalmazásokat alapesetben is csoportszervezési és tájékoztatási feladatokra hozták létre, így egyértelmüen müködnek a katasztrófavédelmi önkéntesek szervezése, katasztrófavédelmi felkészítése kapcsán is. Fontos ugyanakkor a hivatásos szervezet részéről az érintett témákban a szervezettség és a kontroll megvalósítása, mert anélkül a folyamatok a gyorsaságukból adódóan könnyen kaotikussá válhatnak. Ennek megoldása lehetne egy okoseszközökön használható katasztrófavédelmi (felhasználóbarát, könnyen kezelhető, önkéntes nyilvántartást 
végző, riasztásra alkalmas, oda-vissza kommunikációra képes, biztonsági funkciókkal ellátott) applikáció megalkotása, amely nagymértékben javítaná az önkéntesek szervezését.

A harmadik hipotézis is egyértelműen igazolható. Annak tudatában, hogy az önkéntes társadalom szinte teljes spektrumban használja a mobil okoseszközöket és a közösségi alkalmazásokat, a védekezések szervezőinek erre tudatosan készülni kell. Az előre látható, hogy az eszközök használata jelentősen javíthatja a hatékonyságot, erre azonban nem csak az önkéntes oldalnak kell felkészülnie (hiszen a kommunikáció minimum két résztvevős folyamat), ugyanis a tudatos katasztrófavédelmi szervezés és irányítás nélkül ezen lehetőségek kihasználása nem, vagy nem hatékony módon valósul meg. A védekezést szervező állományt a programok és alkalmazások használatára fel kell készíteni, csakúgy, mint arra a lehetőségre, hogy például a veszélyhelyzeti kommunikáció új formái is megjelenhetnek - például egy önkéntes élö Facebook bejelentkezése és közvetítése a direkt kárterületröl.

\section{KÖVETKEZTETÉSEK}

A kérdőíves kitöltések elemzésének segítségével a kutatás során felmerült kérdésekre sikerült választ kapnunk. Megállapítható, hogy a Veterán generációt leszámítva szinte mindenki más nagyon nagy arányban képes használni a számítástechnikai és okoseszközöket, mobiltelefonokat és az internetet. A saját eszközökkel internetet elérni nem tudó katasztrófavédelmi önkéntesek száma 5\% alatti értéket mutat, míg egyre növekszik azok száma, akik akár a 24 órás, azaz a folyamatos internetelérésre képesek. A téma egyik kiemelkedő értékelt eredménye, hogy a Baby Boom generáció több mint a fele, az X, Y, Z generációk legalább kétharmada 2 órán belül ellenőrzi az elektronikus eszközén beérkezö újdonságokat. Ez megalapozhatja azon gondolatot, hogy egyre inkább megvalósítható és hatékonnyá tehető a katasztrófavédelmi önkéntesek okoseszközökön történő elérése, felkészítése, csoportba szervezése. A felkészítések kapcsán egyértelmüen bebizonyosodott, hogy ahol rendszeresen történnek képzések és gyakorlatok, ott az önkéntesek ismeretszintje is magasabb. Indokolt tehát a katasztrófavédelmi feladatok kockázatalapú megközelítésével a veszélyforrásokat azonosítani, majd az önkéntesek részére az adott veszélyeztető hatás elleni védekezésre vonatkozó célfelkészítésekkel emelni a képzettségi szintet.

\section{FELHASZNÁLT IRODALOM}

[1] KISSNÉ ANDRÁS K.: A Magyar Honvédség Hivatásos és szerzödéses állományának, valamint a versenyszféra motiváltságának összehasonlitó elemzése. Doktori értekezés. https://ludita.uninke.hu/repozitorium/bitstream/handle/11410/9954/Kissn\%C3\%A9\%20Andr\%C3\%A1s $\% 20 \mathrm{~K} 1 \% \mathrm{C} 3 \% \mathrm{~A} 1 \mathrm{ra} \% 20 \% \mathrm{C} 3 \% \mathrm{~A} 9 \mathrm{rtekez} \% \mathrm{C} 3 \%$ A9s? sequence=1\&isAllowed=y (letöltve: 2018.11.17.)

[2] HÁBERMAYER T.: A magyar önkéntesek kategóriái és lehetséges fejlesztésük iránya az ár- és belvizek elleni védekezések tükrében Védelem Tudomány 2017. 2. szám p 88-124. http://www.vedelemtudomany.hu/articles/07-habermayer.pdf (letöltve: 2018.11.17.)

[3] 2011. évi CXXVIII. törvény a katasztrófavédelemről és a hozzá kapcsolódó egyes törvények módosításáról. http://njt.hu/cgi_bin/njt_doc.cgi?docid=139408.338506 (letöltve: 2018.11.17.)

[4] Veszélyhelyzeti Értesítési Szolgáltatás http://www.katasztrofavedelem.hu/index2.php?pageid=szervezet_hirek\&hirid=5159 (letöltve: 2018.11.17.) 
[5] MUHORAY Á.: Katasztrófamegelőzés I., NKE Szolgáltató Nonprofit Kft. 2016. ISBN 978-615-5527-85-2 http://ludita.uni-nke.hu/repozitorium/handle/11410/10287 (letöltve: 2018.11.17)

[6] Vízügyi Geoinformációs Portál https://geoportal.vizugy.hu/atlasz/ (letöltve: 2018.11.17.)

[7] Echo112 - Web Emergency Locator https://www.echo112.com/en/ (letöltve: 2018.11.17.)

[8] Nina - Die Warn-App des BBK https://www.bbk.bund.de/DE/NINA/WarnApp_NINA_node.html (letöltve: 2018.11.17.)

[9] TEKNÖS L.: Exploring the possibilities of citizen preparation for extreme weather events - an international outlook. Hadmérnök, XIII. Évfolyam 4 szám - 2018. december. pp. 241-260. ISSN 1788-1919. http://hadmernok.hu/184 19 teknos.pdf (letöltve: 2018.12.31.) 